\title{
Estimating total factor productivity in the Saudi Arabia construction sector
}

\author{
تقير الاتلجية الكلية لغنار الاتتاج في قطاع الاشاءات في المملكة العربية السعوبية
}

\begin{abstract}
The study aims to estímate the total factor productivity in Saudi Arabia construction sector. Using Cobb Douglas production function. The results showed that that there is a long-run equilibrium relationship between the value of production and the factors of production labour and capital. The study also showed that the coefficient of labour is positive with a value of 0.015 . While the elasticity of production with respect to capital is about 0.42 the elasticity of production with respect to the capital component is greater than the labour component and the construction sector in KSA operates in light of decreasing returns to scale (DRS). The results indicates that the construction sector in Saudi Arabia during the coming years will witness a positive growth rate with interest in strengthening the partnership between the government and the private sector in order to develop the construction sector. The study also recommends expanding the production process within the construction sector and moving towards research and development in the field of construction and working to increase investment in the human capital component by training employment and encouragement of investment, in addition to, loans facilitates to the construction sector.
\end{abstract}

Keywords: Saudí Arabia, Total Factor Productivity, Construction Sector, Cobb Douglas production function.

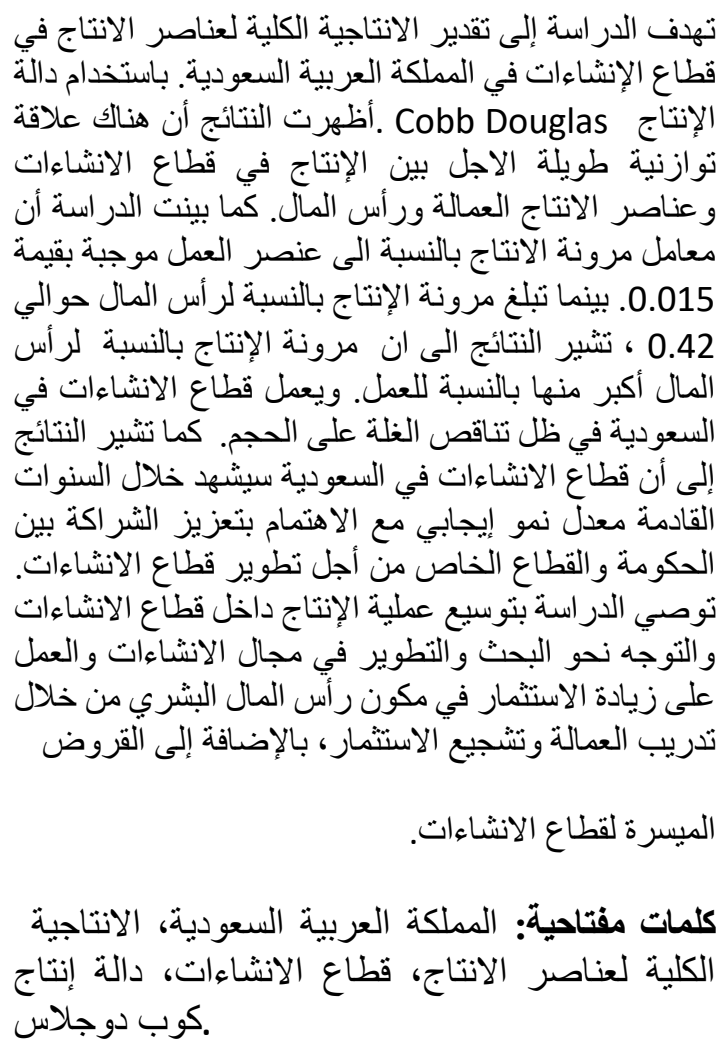

${ }^{13}$ Assistant Professor, Department of Finance and Banking, College of Business Administration, Dar Aluloom University, Riyadh, KSA, Saudi Arabia.

${ }^{14}$ MBA Student, College of Business Administration, Dar Aluloom University, Riyadh, Saudi Arabia.

${ }^{15}$ MBA Student, College of Business Administration, Dar Aluloom University, Riyadh, Saudi Arabia.

${ }^{16}$ MBA Student, College of Business Administration, Dar Aluloom University, Riyadh, Saudi Arabia. 


\section{Introduction}

Construction sector plays a major role in expanding cities to accommodate more people and more economic activities. However, it is not just the creation of bigger cities, which helps the building increase productivity. The relationship to labour mobility is well documented and accepted in the government productivity plan. Political choices, financing and economic factors are the main influencing factors in the market. The Labour market also depends on providing affordable housing in the suitable places, In addition to the need for more housing (Green, 2016). In the current global economic conditions, improving the productivity of the construction sector is more urgent than ever. Several factors affect the efficiency of construction activities, but one of the big challenges facing the construction sector is low productivity (Jarkas \& Radosavljevic, 2013).

The construction sector is one of the important economic sectors in the Saudi Arabia economy. The importance of this sector is evident in its contribution to the GDP, in creating new job opportunities, and in its intertwining with other economic sectors.

The construction sector in Saudi Arabia is witnessing remarkable growth, and the improvement of economic indicators in the Kingdom has led to positive results on the performance of the construction sector in the Kingdom and the strengthening of its material and technical capabilities. The Kingdom is also interested in strengthening its efforts to develop the sector through development plans. The construction activity has recorded high growth rates, the growth amounted to $6.75 \%$ in 2014 due to continued government spending on infrastructure projects, then growth rates declined again in 2016 to reach $3.2 \%$, then the construction sector recorded a remarkable growth rate again $3.3 \%$ in 2017.

The construction sector contributed about 5.5\% of the GDP in 2019 and $7.3 \%$ of the non-oil GDP at current prices, compared with $5.17 \%$ in 2018 (Saudi Central Bank, 2020). according to data issued by the General Authority for Statistics the sector also recorded a growth of $4.6 \%$ in real terms in 2019 outperforming the non-oil GDP growth rate of $3.3 \%$, this represents a significant improvement over previous years, when the sector shrank by $3.2 \%$ in 2016 and $3.3 \%$ in 2017 and $3.5 \%$ in 2018 .
The financial environment has been the main driver of the decline in construction activity in the kingdom since 2015, the lower oil prices slowing economic growth and controlling the budget resulting in subsidy cuts and cuts in government expenditures. Since mid-2014, the price of crude oil has fallen from over $\$ 100$ to about $\$ 50$ in early 2015 , dropping further to $\$ 30$ in early 2016 before recovering to $\$ 60$ in late 2017. As a result, overall economic growth has declined. The rate subsequently increased to $1.4 \%$ in 2016 , the slowest rate since the global financial crisis in 2009. While the rate showed greater resilience to the economy amid lower oil prices, it shook the kingdom after several years of high growth. This has had an indirect effect on the market: real estate activity closely related to broader economic growth and investor confidence, which depend on demand for private construction. In addition, the construction sector supported by public investment in building infrastructure, which has slowed during this period (Oxford business group, 2018).

The year 2019 witnessed mergers, with no major changes in fiscal policy, which provided a period of stability. However, while the sector has broken the negative growth trend in 2019, the impact of Covid-19 could see another contraction in 2020 and about 56 billion Saudi riyals ( $\$ 14.9$ billion) have been allocated to infrastructure and transportation in the 2020 budget, which represents $5.5 \%$ of the total, and private sector participation is expected to add to this investment. It is noteworthy that the share of the local private sector in ownership of capital in the Saudi construction sector amounted to about $91 \%$, and $8 \%$ for the foreign sector, the government only contributes about $1 \%$ in the ownership of the capital (General Authority for Statistics, 2018). This reflects the importance of the contribution to the private sector GDP in the Kingdom.

The construction sector employed about $16 \%$ of total employment and $87 \%$ non-Saudi workforce and $13 \%$ of the Saudi workforce in 2017(General Authority for Statistics, 2017), 88\% non-Saudi workforce and $12 \%$ of the Saudi workforce in 2018 (General Authority for Statistics, 2018). The total number of workers in the construction sector increased from 1.06 million Workers in 2017 , to about 2.3 million workers in 2019. On the other hand, we find that the percentage of bank credit granted to the construction sector out of total bank credit is $4.3 \%$ on average during the period (1970-2019) (Alzyadat, 2021). Moreover, 


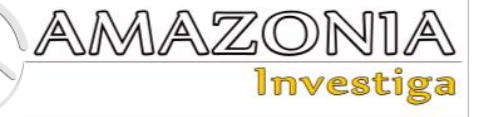

the study by Alzyadat (2021) found a positive and significant impact of bank credit to construction sector on the non-oil GDP growth in Saudi Arabia.

Within the Kingdom's vision 2030, which includes a strategic plan aimed at transforming the Kingdom into a diversified economy. The plan included a strategy for the development of the construction sector. The funding allocated to the construction sector within the framework of Vision 2030 and the short-run national transformation program 2020 has reached about \$ 90 billion for new public transport in Riyadh, Jeddah, Makkah and Madinah. \$ 8 billion for expanding the railway network, and $\$ 60$ billion for water utilities. The focus of Vision 2030 also included the development of the health, defense, transport and logistical services sectors that require building and construction for development. As well as building hospitals, factories and infrastructure, and the strategic plan aims to reduce the volume of government expenditures on the sector and increase the private sector's expenditures on the sector. Which represents about $70 \%$ of Contracts awarded by the government in 2016 , as well as housing projects paid by the private and government sector.

This study aims to clarify the importance and measure the role of productivity of the production factors in the construction sector growth, by estimating the contribution of capital and the labour force in the sector's production. The importance of the study is due to the remarkable growth and real boom that occurred in the construction sector in Saudi Arabia and the increased demand for construction services.

\section{Literature Review}

Total factor productivity (TFP) interpreted in the literature in different, mutually contradictory ways (Lipsey \& Carlaw, 2004). TFP is the portion of output not explained by the amount of inputs used in production. As such, its level is determined by how efficiently and intensely the inputs are utilized in production (Comin, 2010). TFP shows how much output was actually produced from a given amount of input (Isaksson, 2007). TFP plays a critical role on economic fluctuations, economic growth and cross-country per capita income differences. At business cycle frequencies, TFP is strongly correlated with output and hours worked (Comin, 2010). (TFP) can be taken as a measure of an economy's long run technological change or technological dynamism (Lipsey \& Carlaw, 2000).

Total factor productivity in construction sector has been an important topic of empirical studies, in large part because the measured of total factor productivity growth in construction in recent decades has lagged far behind other industries. Tan, (2000) estimated the (TFP) for the Singapore construction industry. The results indicated that the capital accumulation was the main contribution to real construction output growth. TFP was found to be negative, indicating that construction productivity growth has not been spectacular. While, Zhi, et al., (2003) applied Jorgenson's method to estimate TFP growth in the construction industry of Singapore. The study found that the performance of TFP in the construction industry lags behind the rest of economy. Also, found the TFP growth is fluctuating over time and tends to move in tandem with the construction business cycle. Seven factors are closely related to the growth of TFP, among them: economies of scale, R\&D by the industry, investment allowance granted and labour unions are leading contributors to TFP growth; while foreign worker, construction accidents and pre-cast are major hampers. As well as Navaratna \& Jayawardane, (2007) used the Tornqvist Index method to estimate the TFP Growth of the Sri Lanka building construction industry. The results indicated that TFPG has a positive trend from 1995 to 1997, the maximum TFPG recorded in 1997. However, there is a drastic drop in TFPG (from +0.803 to -0.682 ) in the building construction in 1998 and 1999 due to very high labour and capital input compared to 1997. Since 2000, the TFPG in the building construction industry had been revolving around zero. While $\mathrm{Li}$ and Liu, (2010) employed the Malmquist index method to estimate the total factor productivity of the Australian construction industry during the period 1990-2007. The results of the study consisting of two input variables and one output variable illustrate how construction technology, pure technical efficiency and economies of scale affect construction sector productivity.

Liu, L.P. (2011) analyzed TFP in the transformation of economic growth pattern in Anhui province's construction industry, the study found that the main influencing factors in the development of the construction industry in Anhui Province were capital and labour inputs, and played a weak role in TFP.

Wang, et al, (2013) noted that TFP in China's construction industry is improving steadily; the 
improvement is mainly due to the efficiency of pure technology, technological advancement and volume efficiency. The coefficient of variation in productivity of China's construction industry was generally small and little changed. In addition, Ye, et al, (2019) applied Solow Residual Approach to analyze the impact of migrant workers on TFP in Chinese construction sector. The results indicated that migrant workers have a significant impact on TFP, the migrant workers improved TFP by $10.42 \%$ in total and promoted the annual average TFP growth by $0.96 \%$, the main reason for such impact is believed to be the improvement of migrant workers' quality obtained mainly throughout learning by doing.

Choy, et al., (2015) adopted Solow Model to create TFP of Malaysian Construction Sector. Lending to the construction sector by banking system used as proxy for capital input and number of construction employment as labour input. The result indicates a downtrend for the TFP in 1989-1998 and an uptrend in 1998-2012. The growth of the construction sector in 19891998 was driven by capital injections.

Chancellor and Lu (2016) estimated the construction productivity and efficiency in China; the study found that the construction productivity in China has seen growth from a low base in 1995, the construction industry in China is more efficient by scale than technical proficiency.

Idrovo-Aguirre and Serey (2018) estimated the TFP for the Chilean Construction Sector, based on a Cobb-Douglas production function of sectoral GDP and independent measures of capital and labour, the results showed that the sectoral TFP showed a downward trend. The economic growth of the sector is dominated by the accumulation of factors rather than the efficiency of the production process.

The interest in the productivity of the construction sector has become important in both the construction industry itself and in academic studies. Productivity is now recognized as a formal project management process in construction. However, most of the previous literature has focused on identifying factors affecting productivity at the micro level to investigate the relationship between production factors and productivity (Park, 2006). The study by Robles, et al., (2014) analyzed the factors affecting labour productivity of construction industry in Spanish, the findings of the study revealed the top five factors are as follows: shortage or late supply of materials; clarity of the drawings and project documents; clear and daily task assignment; tools or equipment shortages; level of skill and experience of labour. Likewise, (Rakib et al, 2020) identified the most factors affecting the construction industry productivity in Khulna city of Bangladesh. The results showed that the top five factors affecting construction productivity are labour supervision, skilled labour, availability of materials, availability of equipment, and scheduling of work in Khulna city. As well as, Irfan, et al., (2020) determined the factors affecting labour productivity in Pakistani construction industry. The most significant labour productivity factors are identified as shortage of skilled labour, payment delay by owner to contractor, unrealistic scheduling and expectation of labour performance, clarity of technical specification, and delay in wages payment to Labour. Shortage of skilled labour remained on top in both the ranking techniques. Furthermore, Ahmad, et al, (2020) investigated the macro-economic factors affecting the labour productivity in the Norwegian construction sector. The results suggested that the Norwegian construction labour productivity is not declining and it is actually a productive industry in terms of value added per working hour. Production function in the Jordanian construction sector was estimated using different formulas of production functions. The results of the study by Nazarko and Chodakowska (2015) revealed huge differences in the productivity of the construction industry across Europe countries. The trends in productivity change are also explored, the results confirmed that the interpretation of the efficiency scores without taking into account the general economic conditions of a country may lead to false conclusions. Zhan et al., (2018) identified the key factors influencing the TFP growth; provide insights and solutions to enhancing construction productivity at the industry, organization, and activity levels. The results revealed a downward trend of construction productivity in Hong Kong with a negative average TFP growth rate of $-2.15 \%$ over the period from 2003 to 2014 . Through correlation analyses, this trend was found to be shaped by the factors including work force issues and low material technology progress. Chen, et al., (2018) found that the productivity in China's regional construction is significantly affected by economic environment, industrial organization structure and technological level. Chau, (2009) suggested that the technological progress has been the major source of long run TFP growth in the Hong Kong's building industry. 


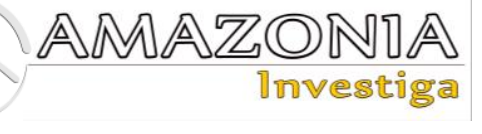

Abdel-Wahab, and Vogl, (2011) found that there is a general slowdown in labour productivity growth in total industries including construction across major OECD countries, with the exception of the UK. The differences in labour productivity growth between construction and total industries can be largely explained by construction's poor TFP performance, the study suggested that the industry has become less efficient in combining the factors of production. Hu, and Liu, (2016) investigated the factors affecting the productivity of the Australian construction industry compared to that achieved by TFP, the results showed that TFP is an improvement in the Australian construction industry, especially with regard to technological development.

Arditi and Mochtar (2000) indicated that cost control, scheduling, design practices, labour training, and quality control are considerable for productivity improvement, whereas materials packaging and foreign developments in construction technologies are perceived consistently as functions that do not have much effect on improving construction productivity. Rojas and Aramvareekul (2003) identified the Management skills and work force issues were the greatest potential to affect labour productivity in the construction industry.

\section{Methodology and Model Specification}

Several methodological issues arise when estimating TFP using conventional methods, the application of ordinary least squares (OLS) estimation has been proposed in previous literature. (Van Beveren, 2012). Since productivity and input choices are likely to be correlated in OLS estimation of production functions introduces a simultaneity or endogeneity problem. The methodology of the study depends on the descriptive analysis method in order to analyze the data and estimate the productivity of the construction sector in Saudi Arabia, so the study use the quantitative method in order to estimate the production function and measure the total factor productivity in the construction sector. The study depends on the data collected from the Ministry of Housing, the General Authority for Statistics.

The Productivity of labour and capital can be measured by several approaches, including: labour productivity, which is defined as the average production per worker within a year as follows:

$$
\mathrm{APL}=\frac{Q}{L}, \mathrm{APK}=\frac{Q}{K}
$$

Where Q: Value of output in the sector, L: number of workers $\mathrm{K}$ : capital accumulation

The production function is one of the most important indicators that express the economic variables that link between the quantity produced and the size of the inputs used in the production process. It is important to clarify the concept of the production function to highlight two basic principles, namely: the return to scale, i.e. the response of the production scale to the variables, as well as the substitution rate, the ease of replacement one of the factors of production to another to obtain the same level of output.

The production function has economic importance, as it plays an important role in analyzing the role of contributing factors in production. The results of the production functions analysis also can be used to predict requirements for achieving the necessary levels of labour and capital.

Charles Cobb and Paul Douglas in 1928 introduced the simplest production function used in economics is a Cobb-Douglas production function, Cobb and Douglas (1928) considers a simplified view of the economy in which production output $(Y)$ is determined by the amount of labour $(L)$ involved and the amount of capital (K) invested. This is a two-input production function, and can be formulated as follows:

$$
Y=A \cdot f(K, L)
$$

The production function can be expressed as follows by formulating it mathematically:

$$
\mathrm{Y}=\mathrm{F}(\mathrm{K}, \mathrm{L})
$$

The mathematical relationship shows the relationship of the quantity of output in the construction sector $(Y)$. The quantities of the two factors of production, the capital $(\mathrm{k})$ and labour (L). accordingly the quantity of production $(\mathrm{Y})$ is the dependent variable in the function, while it represents the element of labour and capital they are the factors of production as the independent variables, so the size of production can increase by increasing the size of capital or labour and vice versa. Economic theory assumes that the production factors have positive productivity $(\mathrm{MPL}>0, \mathrm{MPK}>0)$.

There are many forms of production functions to express production process, which can be used to estimate the production function, to describe the relationship between inputs and outputs. Cobb 
Douglas's function is one of the most famous functions; it is characterized by the fact that the elasticity of substitution is constant and equal to one.

The production function coefficients obtained using various estimation techniques. In this study, it is possible to estimate the production function following Cobb Douglas function:

$\mathrm{Y}=\mathrm{A} L^{B_{1}}$

$K^{B_{2}}$

The function can be estimated by converting to the linear logarithmic model as follows:

$$
\operatorname{Ln} Y t=\beta 0+\beta 1 \operatorname{Ln} \mathrm{Kt}+\beta 2 \ln \mathrm{Lt}+\mathrm{Ut}
$$

Where: Ln: natural logarithm, A: The efficiency factor, which independently reflects the change in output as a result of the change in the factors of production. Y: total production, which is the value of products during a certain period. Because of practicing a production process, which is (the production value of the activity + the production value of the secondary activities + the revenues of the services provided + the revenues of the secondary activities). K: The capital formation to which it is the total amount spent by the establishment during the year to own durable goods as an addition to its stock of fixed assets excluding lands minus its net sales of used fixed assets. L: The number of workers in the economic sectors. $U$ : Random error. $(\beta 0, \beta 1, \beta 2)$ : coefficient to be estimated. Where $\beta 0$ : represents the production efficiency factor constant. $\beta 1$ : It represents the elasticity of production with respect to the capital fixed formation $\beta 2$ : It represents the elasticity of production with respect to labour. $(\beta 1, \beta 2)$ can be used to determine whether the inputs exhibit increasing, decreasing, or constant returns to scale, if $(\beta 1+$ $\beta 2>1$ : Increasing return to scale (IRS)) or $(\beta 1+$ $\beta 2<1$ : Decreasing return to scale (DRS)) or $(\beta 1+$ $\beta 2=1$ Constant return to scale (CRS))

\section{Data Analysis and Results}

Estimating the total factors productivity, using the Cobb Douglas function and determining the extent of the relationship between the dependent variable (Y), which represents the value of production in the construction sector. the independent variables (L), which represents the labour component, which is the total number of workers in the construction sector, and the independent variable $(\mathrm{K})$ which Represents total fixed capital at current prices. The results of the construction sector production function estimation in table (1).

Table (1).

The estimation of the production function.

\begin{tabular}{|c|c|c|c|c|}
\hline $\begin{array}{l}\text { Dependent Variable: Y } \\
\text { Method: Least Squares }\end{array}$ & & & & \\
\hline Variable & Coefficient & Std. Error & t-Statistic & Prob. \\
\hline $\mathrm{L}$ & 0.014734 & 0.003589 & 4.105881 & 0.0063 \\
\hline K & 0.421565 & 0.115056 & 3.663985 & 0.0105 \\
\hline $\mathrm{C}$ & -9799.695 & 36544.25 & -0.268160 & 0.7976 \\
\hline R-squared & 0.781825 & Mean dependent var & & 134901.0 \\
\hline Adjusted R-squared & 0.709100 & S.D. dependent var & & 26757.38 \\
\hline S.E. of regression & 14431.64 & Akaike info criterion & & 22.25343 \\
\hline Sum squared resid & $1.25 \mathrm{E}+09$ & Schwarz criterion & & 22.31918 \\
\hline Log likelihood & -97.14046 & Hannan-Quinn criter. & & 22.11156 \\
\hline F-statistic & 10.75042 & Durbin-Watson stat & & 1.948739 \\
\hline $\operatorname{Prob}($ F-statistic) & 0.010385 & & & \\
\hline
\end{tabular}

Source: Researchers' work EViews Program Outputs

The results indicate that the ( $\mathrm{P}$ value $<0.05)$ ) that is, the value is significant, therefore we reject the null hypothesis (there is no long-run equilibrium relationship) and accept the alternative assumption, i.e. that there is at least a long-run equilibrium relationship between the value of production and the factors of production (labour and capital).
The value of $t$ Statistic is significante, which means that the independent variables have an effect on the dependent variable. The value of the coefficient of the two independent variables is positive and significant. Therefore, there is a positive relationship between the two independent variables and the dependent variable, and this is economically acceptable, that is, the model corresponds to economic 


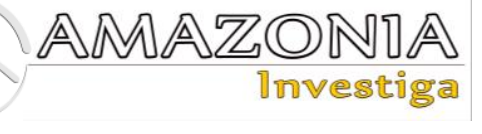

theory, and there is a positive relationship between constriction sector production and production factors (Labour and capital). The coefficient of labour is positive with a value of 0.015 . That is, the elasticity of production with respect to labour is about 0.015 , meaning that an increase in the labour component by $100 \%$ leads to an increase in construction sector production by $1.5 \%$. While the elasticity of production with respect to capital is about 0.42 , that is, an increase in capital by $100 \%$ leads to an increase in construction sector production by $42 \%$. The relative importance of the labour and capital component in production, it was found that the share of the labour component in production is low, as well as the low capital contribution index, and that the low of these ratios means a decrease in efficiency in using the production factors. The low percentage of these two indicators confirms that the construction sector in the KSA is still a traditional one and does not depend on modern technology in production processes. the sum of estimated Coefficient in the model are 0.45 , which means that the construction sector in KSA operates in light of decreasing returns to scale (DRS), meaning that an increase in factors of production by $100 \%$ will lead to an increase in the production by $45 \%$.

\section{Conclusions}

The total factors productivity of the construction sector reflects the efficient use of the available resources needed for the development of the sector, the effectiveness of management and the optimal use of resources. Productivity is closely related to competitiveness. The study aimed to analyze the reality of the construction sector in Saudi Arabia by estimating the total factors productivity using the Cobb Douglas production function. The results showed that there is a long run relationship between the production and the factors of production (labour and capital). The results confirms the positive relationship between construction sector production and the production factors (Labour and capital). The coefficient of labour is positive with a value of 0.015 . while the elasticity of production with respect to capital is about 0.42 the elasticity of output with respect to the capital component is greater than in the case of the labour component and this indicates the adoption of the construction sector within The kingdom is on the capital, with little workforce in the sector. the results reveals the sum of estimated Coefficient in the model are 0.45 , which means that the construction sector in KSA operates in light of decreasing returns to scale (DRS). While the results of the study Alzyadat and Almuslamani (2021) which find the elasticity of the wholesale and retail trade production in Saudi Arabia with respect to capital and labour are 0.26 and 0.78 respectively.

The growth rate of the construction sector in Saudi Arabia during the coming years will witness the growth rate, with Saudi Arabia's interest in strengthening the partnership between the government and the private sector in order to develop the construction sector. The Kingdom will also lead many large projects and large residential housing plans within the Kingdom's 2030 strategy and vision. It is expected that the sector will witness Construction is a major activity within it and the growing tourism industry is also expected to be a driver, as the Saudi Arabia prepares for an influx of visitors due to the new tourist visa, there will be more room to reconsider infrastructure requirements, including accommodation and urban transport. Good for growth, but Covid-19 may cause the disruption of new projects and contracts, which were expected to continue throughout 2021. The study also recommends expanding the production process within the construction sector and moving towards research and development in the field of construction and increase investment in the work force component through training, employment and encouragement of investment, in addition, to encourage the policy of loans facilitating to the sector.

\section{Acknowledgement}

The authors extend the appreciation to the Deanship of Post Graduate and Scientific Research at Dar Al Uloom University for supporting and funding this research.

\section{References}

Abdel-Wahab, M., \& Vogl, B. (2011). Trends of productivity growth in the construction industry across Europe, US and Japan. Construction Management and Economics, 29(6), 635-644 https://doi.org/10.1080/01446193.2011.573568 Ahmad, S.B.S., Mazhar, M.U., Bruland, A., Andersen, B.S., Langlo, J.A., \& Torp, O. (2020). Labour productivity statistics: a reality check for the Norwegian construction industry. International Journal of Construction Management, 20(1), 39-52. https://doi.org/10.1080/15623599.2018.1462443 Alzyadat, J.A., \& Almuslamani, M.S. (2021). The Role of Technological Progress in the Distribution sector: Evidence from Saudi Arabia Wholesale and Retail Trade Sector. Journal of Distribution Science 19, 19(3), 15-23. https://doi.org/10.15722/JDS.19.3.202103.15 
Alzyadat, J.A. (2021). Sectoral Banking Credit Facilities and Non-Oil Economic Growth in Saudi Arabia: Application of the Autoregressive Distributed Lag (ARDL). The Journal of Asian Finance, Economics, and Business, 8(2), 809-820.

https://doi.org/10.13106/jafeb.2021.vol8.no2.08 09

Arditi, D., \& Mochtar, K. (2000). Trends in productivity improvement in the US construction industry. Construction Management \& Economics, $\quad 18(1), \quad 15-27$. https://doi.org/10.1080/014461900370915

Chancellor, W., \& Lu, W. (2016). A regional and provincial productivity analysis of the Chinese construction industry: 1995 to 2012. Journal of construction engineering and management, 142(11), 05016013. https://doi.org/10.1061/(ASCE)CO.19437862.0001177

Chau, K.W. (2009). Explaining total factor productivity trend in building construction: Empirical evidence from Hong Kong. International Journal of Construction Management, 9(2), 45-54. https://doi.org/10.1080/15623599.2009.1077312 8

Chen, Y., Liu, B., Shen, Y., \& Wang, X. (2018). Spatial analysis of change trend and influencing factors of total factor productivity in China's regional construction industry. Applied Economics, 50(25), 2824-2843. https://doi.org/10.1080/00036846.2017.1409421 Choy, C.F., Skitmore, M. \& Yan, F.Y. (2015). Total factor productivity in the Malaysian construction sector. In 21st Annual Pacific-Rim Real Estate Society Conference, Malaysia.

Cobb, C. W., \& Douglas, P. H. (1928). A theory of production. The American Economic Review, 18(1), 139-165.

Comin, D. (2010) total factor productivity. In: Durlauf S.N., Blume L.E. (eds) Economic Growth. London: The New Palgrave Economics Collection. Palgrave Macmillan, 260-263. https://doi.org/10.1057/9780230280823_32

General Authority for Statistics. (2017). Survey of construction activity 2017 https://www.stats.gov.sa/en/1004-0

General Authority for Statistics. (2018). Survey of construction activity 2018. https://www.stats.gov.sa/en/1004-0

Green, B. (2016) Productivity in Construction: Creating a framework for the industry to thrive. Bracknell, UK: Chartered Institute of Building (CIOB)

Hu, X., \& Liu, C. (2016). Energy productivity and total-factor productivity in the Australian construction industry. Architectural Science
Review, 59(5), 432-444. https://doi.org/10.1080/00038628.2015.1038692 Idrovo-Aguirre, B.J. and Serey, V.D. (2018). Total Factor Productivity for the Chilean Construction Sector (1986-2015). Journal of Economic Analysis, 33(1), 29-54.

Irfan, M., Zahoor, H., Abbas, M., \& Ali, Y. (2020). Determinants of labor productivity for building projects in Pakistan. Journal of Construction Engineering, Management \& Innovation, $\quad 3(2), \quad 85-100$. https://doi.org/10.31462/jcemi.2020.02085100 Isaksson, A. (2007). Determinants of total factor productivity: a literature review. Research and Statistics Branch, UNIDO.

Jarkas, A. M., \& Radosavljevic, M. (2013). Motivational factors impacting the productivity of construction master craftsmen in Kuwait. Journal of Management in Engineering, 29(4), 446-454.

Li, Y., \& Liu, C. (2010). Malmquist indices of total factor productivity changes in the Australian construction industry. Construction Management and Economics, 28(9), 933-945. https://doi.org/10.1080/01446191003762231

Lipsey, R.G., \& Carlaw, K. (2000). What does total factor productivity measure?. International Productivity Monitor, 1, 31-40.

Lipsey, R.G., \& Carlaw, K.I. (2004). Total factor productivity and the measurement of technological change. Canadian Journal of Economics, 37(4), 1118-1150. https://doi.org/10.1111/j.0008-

4085.2004.00263.x

Liu, L.P. (2011). An Empirical Analysis of the Function of STP to the Economic Growth in Construction Industry Based on TFP Theory-A Case Study of Anhui Province. Advanced Materials Research, 243, 6418-6424. https://doi.org/10.4028/www.scientific.net/AM R.243-249.6418

Navaratna, D. \& Jayawardane, A.K.W. (2007). Total Factor Productivity in the Building Construction Industry in Sri Lanka. ENGINEER, 20(1), 63-70

Nazarko, J., \& Chodakowska, E. (2015). Measuring productivity of construction industry in Europe with Data Envelopment Analysis. Procedia Engineering, 122, 204-212. https://doi.org/10.1016/j.proeng.2015.10.026

Oxford business group. (2018). Building activity in Saudi Arabia picks up as government launches new projects. Saudi Arabia report. https://oxfordbusinessgroup.com/saudi-arabia2018

Park, H. S. (2006). Conceptual framework of construction productivity estimation. KSCE Journal of Civil Engineering, 10(5), 311-317. https://doi.org/10.1007/BF02830084 


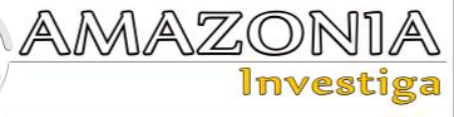

Rakib, F.H., Howlader, S., Rahman, M., \& Hossain, A. (2020). Factors Affecting the Construction Productivity in the Context of Khulna City of Bangladesh. In Proceedings of the 5th International Conference on Civil Engineering for Sustainable Development, Khulna, Bangladesh (pp. 7-9).

Robles, G., Stifi, A., Ponz-Tienda, J.L., \& Gentes, S. (2014). Labor productivity in the construction industry-factors influencing the Spanish construction labor productivity. International Journal of Civil and Environmental Engineering, 8(10), 1061-1070.

Rojas, E.M., \& Aramvareekul, P. (2003). Labor productivity drivers and opportunities in the construction industry. Journal of management in engineering, $19(2)$ 78-82. https://doi.org/10.1061/(ASCE)0742597X(2003)19:2(78)

Saudi Central Bank, (2020). Fifty sixth Annual Report. https://www.sama.gov.sa/enus/economicreports/pages/annualreport.aspx

Tan, W. (2000). Total factor productivity in Singapore construction. Engineering construction and architectural management, 7(2), 154-158. https://doi.org/10.1046/j.1365232x.2000.00146.x

Van Beveren, I. (2012). Total factor productivity estimation: A practical review. Journal of economic surveys, 26(1), 98-128. https://doi.org/10.1111/j.1467-

6419.2010.00631.x

Xueqing, W., Chen, Y., Liu, B., Shen, Y. \& Sun, H. (2013) A total factor productivity measure for the construction industry and analysis of its spatial difference: a case study in China, Construction Management and Economics, 31(10), 1059-1071, https://doi.org/10.1080/01446193.2013.826371 Ye, G., Wang, Y., Zhang, Y., Wang, L., Xie, H., Fu, Y., \& Zuo, J. (2019). Impact of migrant workers on total factor productivity in Chinese construction industry. Sustainability, 11(3), 926. https://doi.org/10.3390/su11030926

Zhan, W., Pan, W., Javed, A.A., Chau, K.W. (2018) Correlation Analysis of Key Influencing Factors to the Total Factor Productivity of the Hong Kong Construction Industry. In: Chau K., Chan I., Lu W., Webster C. (eds) Proceedings of the 21st International Symposium on Advancement of Construction Management and Real Estate. Springer, Singapore. https://doi.org/10.1007/978-981-10-6190-5_51 Zhi, M., Hua, G. B., Wang, S. Q., \& Ofori, G. (2003). Total factor productivity growth accounting in the construction industry of Singapore. Construction management and economics, 21(7), 707-718. https://doi.org/10.1080/0144619032000056126 